\title{
Regulation of Catecholamine-Synthesising Enzymes and B-Adrenoceptors Gene Expression in Ventricles of Stressed Rats
}

\author{
N. SPASOJEVIC ${ }^{1}$, L. GAVRILOVIC ${ }^{1}$, S. DRONJAK ${ }^{1}$ \\ ${ }^{1}$ Laboratory of Molecular Biology and Endocrinology, Institute of Nuclear Sciences "Vinca", \\ Belgrade, Serbia
}

Received December 22, 2010

Accepted February 16, 2011

On-line July 19, 2011

\begin{abstract}
Summary
Stress exposure activates the sympathoneural system, resulting in catecholamine release. Chronic stress is associated with development of numerous disorders, including cardiovascular diseases. Here we investigated the expression of mRNAs for catecholamine biosynthetic enzymes tyrosine-hydroxylase, dopamine- $\beta$-hydroxylase and phenylethanolamine $\mathrm{N}$-methyltransferase, and for $B_{1}$ - and $B_{2}$-adrenoceptors in the right and left ventricles of rats exposed to chronic unpredictable mild stress. The tyrosine-hydroxylase and dopamine-ß-hydroxylase mRNA levels were not affected by stress, whereas the phenylethanolamine $\mathrm{N}$-methyltransferase mRNA levels significantly increased in both right and left ventricles. No changes in $B_{1}$-adrenoceptor mRNA levels in either right or left ventricles were observed. At the same time, stress produced a significant increase of $\beta_{2}$-adrenoceptor mRNA levels in left ventricles. These results suggest that elevated expression of phenylethanolamine $\mathrm{N}$-methyltransferase in both ventricules and $B_{2}$-adrenoceptor genes in left ventricles could provide a molecular mechanism that leads to altered physiological response, which is important for the organism coping with stress.
\end{abstract}

\section{Key words}

Chronic stress - Ventricles - Catecholamine enzymes • B-adrenoceptors $\bullet$ Gene expression

\section{Corresponding author}

N. Spasojevic, Institute of Nuclear Sciences "Vinca", Laboratory of Molecular Biology and Endocrinology, P.O.B. 522-090, 11000 Belgrade, Serbia. Tel/Fax: 00381113408688. E-mail: snatally@vinca.rs

\section{Introduction}

Clinical studies have confirmed the correlation of stressful events and pathophysiology observed in depression (Kendler et al. 1999). Numerous authors reported that depression and chronic stress are common causes of cardiovascular diseases (Brosschot et al. 2007, Whang et al. 2009). Also, it has been shown that some individuals are more vulnerable to mild but prolonged stressors (Kessler 1997, Hammen 2005) and chronic unpredictable mild stress (CUMS) became one of widely used stress models. Recently, we demonstrated that rats subjected to CUMS evoked depression-like behavior and had elevated plasma levels of corticosterone (Spasojevic et al. 2008, Dronjak et al. 2007). Others have found that rats subjected to CUMS had increased blood pressure and tachycardia, making this model suitable for the studies of stress-induced cardiovascular diseases (Grippo et al. 2002).

Changes in neuroendocrine function may play a role in linking responsiveness to stressors and cardiovascular function. The evidence suggests that altered activity of autonomic nervous system in depressed patients might be responsible for the increased risk of mortality in individuals with cardiovascular diseases. High plasma catecholamine levels were confirmed as a significant risk predictors of cardiovascular mortality (Peng et al. 2006). Catecholamines increase the cardiac output through their positive effects on chronotropism, inotropism and lusitropism, and also through control of cardiomyocyte growth and death, thus contributing to cardiac remodeling (Santos and Sadari-Bratfisch 2006). Recently, the cells exhibiting all monoaminergic features 
were described in the heart of both adult rodents and humans (Huang et al. 1996). These cells might help to regulate cardiac function in parallel with the autonomic nervous system. They are capable of catecholamine biosynthesis in order to maintain myocardial contractility in the resting state and during stress (Zhuang et al. 2005).

The effects of chronic stress are associated with alterations in gene expression of catecholamine biosynthetic enzymes: tyrosine hydroxylase (TH), dopamine- $\beta$-hydroxylase (DBH) and phenylethanolamine $\mathrm{N}$-methyltransferase (PNMT). According to previous studies, the PNMT gene expression is localised not only in cardiac ganglion cells, but also in a wide range in cardiomyocytes (Kennedy et al. 1995). Recently, we have found that TH and DBH mRNAs are present in the ventricles of adult rats (Gavrilović et al. 2010). Sympathetic nervous system plays a role in the control of cardiac function by stimulating adrenergic receptors (ARs). Both $\beta_{1}$ - and $\beta_{2}$-subtypes of these receptors are present in healthy human heart in the ratio of approximately 5:1 (Bengel and Schwaiger 2004). Their stimulation results in increased heart rate and force of contraction. Brunner-La Rocca et al. (2001) also demonstrated that chronic adrenoceptor stimulation could have a direct cardiotoxic effect.

The aim of the present study was to determine whether the stress-induced depression leads to changes in gene expression of three catecholamine biosynthetic enzymes and two $\beta$-adrenoceptors in right and left cardiac ventricles of adult rats, that could affect normal cardiovascular function.

\section{Material and Methods}

\section{Animals}

Adult, 11-week-old Wistar rat males, maintained under standard laboratory conditions with water and food ad libitum in the groups of four individuals per cage were used. All experiments were conducted in accordance with the rules of animals care proposed by the Serbian Laboratory Animal Science Association. In these experiments, 16 rats were used. One group of animals was subjected to CUMS for 4 weeks. The CUMS procedure, a slight modification of the method by Grippo et al. (2002) was designed to maximize the unpredictable nature of the stressors. The CUMS groups were exposed to the following stressors at random order: continuous illumination (24 h), continuous darkness $(24 \mathrm{~h}), 40^{\circ}$ cage tilt along the vertical axis $(17 \mathrm{~h})$, crowding $(8$ rats per cage, $24 \mathrm{~h}$ ), soiled cage ( $300 \mathrm{ml}$ water spilled onto the bedding, $17 \mathrm{~h}$ ), restraint in a small cage $(1 \mathrm{~h})$, cold room $\left(4{ }^{\circ} \mathrm{C}, 7 \mathrm{~h}\right)$, individual housing $(24 \mathrm{~h})$, forced running $(15 \mathrm{~min})$ and food and water deprivation $(7 \mathrm{~h})$. Animals were also maintained on a reversed light/dark cycle from Friday evening to Monday morning. The CUMS procedure applied for a single week was repeated during the following 4 weeks. After that, the animals exposed to CUMS and the corresponding controls were decapitated, the right and left heart ventricles rapidly dissected, frozen in liquid nitrogen and stored at $-70{ }^{\circ} \mathrm{C}$ until analyzed.

\section{Real-time RT-PCR}

Total RNAs were isolated using TRIZOL reagent (Invitrogen, CA, U.S.A.). Reverse transcription was performed using Ready-To-Go You-Prime FirstStrand Bead (AP, Biotech) and pd $(\mathrm{N})_{6}$ primer according to manufacturer's protocol. TaqMan PCR assays were carried out using Assay-on-Demand Gene Expression Products (Applied Biosystems, USA) for TH (Rn00562500_m1), DBH (Rn00565819_m1), PNMT (Rn01495589_g1), $\beta_{1}$-AR (Rn 00824536_s1), and $\beta_{2}$-AR (Rn 00560650_s1) The reactions were performed in a $25 \mu \mathrm{l}$ reaction mixture containing 1x TaqMan Universal Master Mix with AmpErase UNG, 1x Assay Mix (Applied Biosystems) and cDNA template (10 ng of RNA converted to cDNA). PCR reactions were performed in the ABI Prism 7000 Sequence Detection System at $50{ }^{\circ} \mathrm{C}$ for $2 \mathrm{~min}, 95^{\circ} \mathrm{C}$ for $10 \mathrm{~min}$, followed by 40 cycles at $95{ }^{\circ} \mathrm{C}$ for $15 \mathrm{sec}$ and $60{ }^{\circ} \mathrm{C}$ for $1 \mathrm{~min}$. A reference, endogenous control, was included in each analysis to correct the differences in the inter-assay amplification efficiency and all transcripts were normalized to cyclophyline A (ID:Rn 00690933) expression. Quantification was done using the $2^{-\Delta \Delta \mathrm{Ct}}$ method according to Livak and Schmittgen (2001).

\section{Statistical analysis}

The results are reported as means \pm S.E.M. Significance of the differences in gene expression levels were estimated by two-way ANOVA test. The Tukey post hoc test was used to evaluate the differences between the groups. Statistical significance was accepted at $\mathrm{p}<0.05$.

\section{Results}

CUMS did not lead to significant changes in relative gene expression of $\mathrm{TH}$ and $\mathrm{DBH}$ in the rat 
ventricles. The relative gene expression of TH enzyme in right ventricule was $1.09 \pm 0.07$ in controls and $0.97 \pm 0.15$ in stressed animals and in left ventricule was $1.31 \pm 0.17$ in controls and $1.45 \pm 0.15$ in stressed animals. The relative DBH-mRNA levels in left and right ventricules of control animals was $1.04 \pm 0.13$ and $1.05 \pm 0.11$, respectively, whereas in stressed animals it was $1.17 \pm 0.11$ and $1.14 \pm 0.14$. In contrast, post-hoc analysis showed that this stressful procedure increased the PNMT mRNA levels both in the right and left ventricles (by $42 \%$, p $<0.01$ and $19 \%, \mathrm{p}<0.05$, respectively) (Fig. 1).

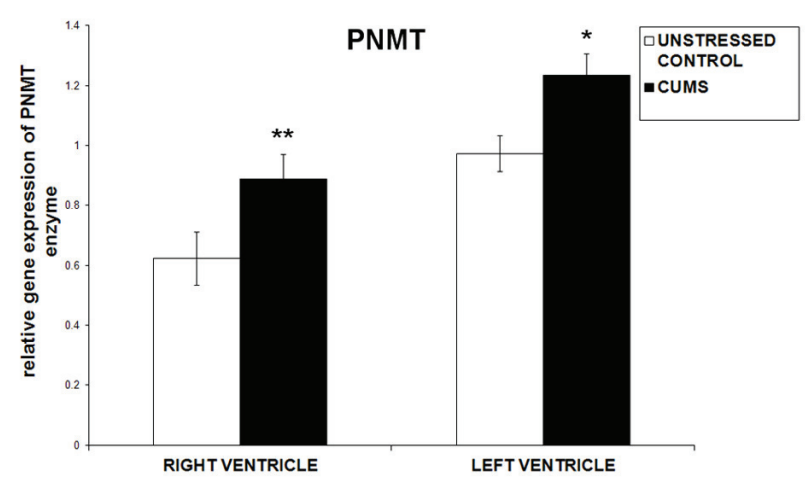

Fig. 1. Chronic unpredictable mild stress-related (CUMS) changes in phenylethanolamine N-methyltransferase (PNMT) mRNA levels in right and left ventricle of adult rat males. The values are means \pm S.E.M. of 6-8 rats. Statistical significance: $* p<0.05$, $* * p<0.01$ (Tukey test) CUMS vs. control. The final result was expressed as fold change relative to the calibrator and normalized to cyclophyline A.

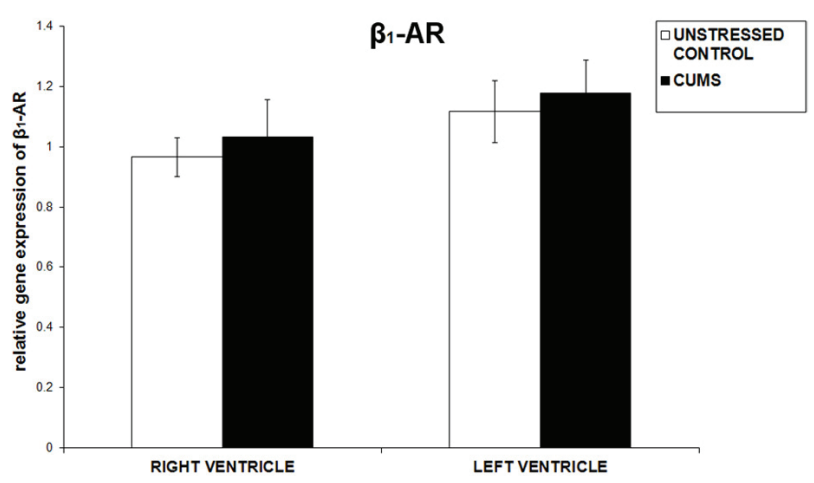

Fig. 2. Chronic unpredictable mild stress-related (CUMS) changes in $B_{1}$-adrenoceptors mRNA levels in right and left ventricle of adult rat males. The values are means \pm S.E.M. of 6-8 rats. The final result was expressed as fold change relative to the calibrator and normalized to cyclophyline $A$.

The gene expression of $\beta_{1}$-ARs remained unchanged in the ventricles after 4 weeks of exposure to CUMS (Fig. 2). However, a significant difference in $\beta_{2}$-AR gene expression between right and left ventricles
$\left(\mathrm{F}_{(1,16)}=18.82, \mathrm{p}<0.001\right)$ was observed. Chronic stress increased the expression of $\beta_{2}$-AR by $40 \%(p<0.01)$ in the left ventricles, but expressed no significant effect on gene expression of this receptor in the right ventricles (Fig. 3).

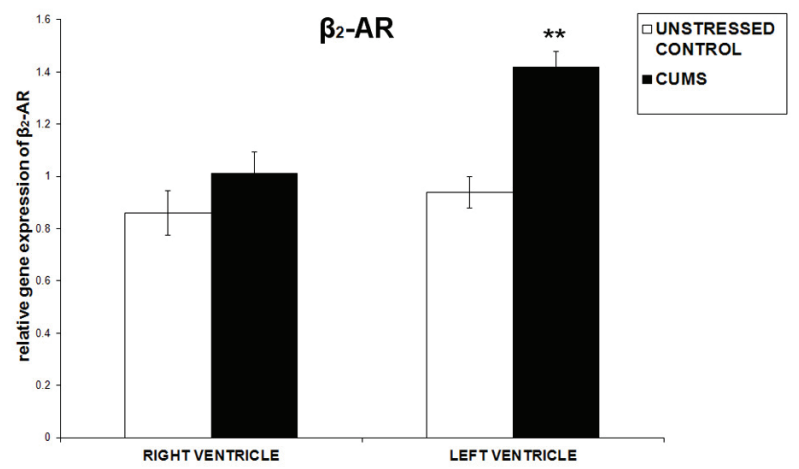

Fig. 3. Chronic unpredictable mild stress-related (CUMS) changes in $B_{2}$-adrenoceptors mRNA levels in right and left ventricle of adult rat males. The values are means \pm S.E.M. of 6-8 rats. Statistical significance: ${ }^{* * p}<0.01$ (Tukey test) CUMS $v s$. control. The final result was expressed as fold change relative to the calibrator and normalized to cyclophyline A.

\section{Discussion}

In the present study, we investigated changes in gene expression of three catecholamine synthesising enzymes in right and left ventricles of rats exposed to CUMS for 4 weeks. Our results demonstrated that CUMS did not affect the levels of TH and DBH mRNAs, while increasing the level of PNMT mRNA in the heart ventricles. Single or repeated 7-day-immobilisation of adult rats also produced an increase of PNMT mRNA levels both in heart atria and ventricles (Kvetnansky et al. 2004, Micutkova et al. 2004). According to Kuroko et al. (2007), myocardial ischemia leads to accumulation of large noradrenaline amounts released from sympathetic nerve endings in interstitial space. This results in the stimulation of increased noradrenaline reuptake in cardiomyocytes, as a form of defense against excessive stimulation of $\beta$-ARs, but also in the stimulation of adrenaline synthesis through PNMT activity. Kaye et al. (1995) confirmed previously possible non-neuronal origin of cardiac adrenaline synthesis and release, which could further facilitate toxic effects and lead to the development of arrhythmia in the ventricles. It was noticed that after myocardial infarction, plasma and ventricular adrenaline levels were markedly increased (Ganguly et al. 1997). Neri et al. (2007) showed that large catecholamine amounts may induce oxidative 
damages through reactive intermediates evolving by their auto-oxidation, independently of their effects on the receptors, thus causing a cardiotoxic effect.

Released catecholamines act increasing contractility in atria and ventricles through their binding to postsynaptic $\beta$-receptors that have chronotropic, dromotropic and inotropic effects (Riemann et al. 2003, Bengel and Schwaiger 2004). In our experiments, a significant increase of $\beta_{2}$-ARs mRNA levels was recorded in left ventricles of rats exposed to CUMS for 4 weeks. Also, these animals were shown previously to have elevated plasma corticosterone levels (Dronjak et al. 2007). Glucocorticoids are known to affect expression of these receptors through GRE sequences in promotor region. Mysliveček et al. (2003) observed that rats treated with hydrocortisone had a higher density of $\beta_{2}$-ARs in the ventricles comparing to the corresponding control. Activation of cardiac $\beta_{2}$-ARs may contribute to an additional increase in heart rate and/or contractility (Khamssi and Brodde 1990). Ventricular cardiomyocytes stimulation of adult rat $\beta_{2}$-adrenoceptors was reported to inhibit apoptosis (Communal et al. 1999). Liggett et al. (2000) demonstrated that heart tolerates enhanced contractile function via 60 -fold $\beta_{2}$-AR overexpression without detriment, but higher levels of expression lead to cardiomyopathy. Also, chronic $\beta_{2}$-AR stimulation with a selective agonist elicits a significant cardiac hypertrophy and impaired cardiac function (Gregorević et al. 2005). Therefore, a small increase in expression of this receptor, observed in CUMS animals, may play a protective role.

However, prolonged exposure to stress could express detrimental cardiovascular effects. Our results showed that despite identical changes in the ventricular expression of catecholamine synthesising enzymes, changes in $\beta$-receptor mRNA levels were visible only in the left ventricles. This is in accordance with the report of
Wang et al. (2006) who also observed different response of the same receptor class in the left and right ventricles. While $\alpha_{1}$-AR stimulation leads to negative inotropic effect in the right ventricle, it expressed a positive inotropic effect in the left ventricles. Besides, these results may also indicate a higher sensitivity of the left ventricles to stress comparing to that of the right ventricles. Yalçin et al. (2010) have shown that there is a regional left ventricular hypercontractility and dysfunction in response to acute and chronic stress. In addition, Li et al. (2001) reported that the noradrenaline transporter expression is higher in the right cardiac sympathetic ganglia of adult rats than in the left ones. Therefore, a greater capacity of noradrenaline uptake in the right ventricles may contribute to the maintenance of right ventricular function under pathological conditions.

In conclusion, our results indicate that CUMS causes elevated expression of PNMT-mRNA in both ventricules and $\beta_{2}$-AR-mRNA in left ventricules. It is reasonable to suggest that such gene and tissue specific response could be of the physiological relevance for the organism coping with stress. However, prolonged exposure to stress can result in pathophysiological changes of heart. Therefore, these results also provide an insight into the molecular mechanisms that may indicate a connection between altered mood and cardiovascular dysfunction.

\section{Conflict of Interest}

There is no conflict of interest.

\section{Acknowledgement}

This work was supported by the Ministry for Science and Technological Development of the Republic of Serbia, Contract No. 143044B.

\section{References}

BENGEL FM, SCHWAIGER M: Assessment of cardiac sympathetic neuronal function using PET imaging. $J$ Nucl Cardiol 11: 603-616, 2004.

BROSSCHOT JF, VAN DIJK E, THAYER JF: Daily worry is related to low heart rate variability during waking and the subsequent nocturnal sleep period. Int J Psychophysiol 63: 39-47, 2007.

BRUNNER-LA ROCCA HP, ESLER MD, JENNINGS GL, KAYE DM: Effect of cardiac sympathetic nervous activity on mode of death in congestive heart failure. Eur Heart J 22: 1136-1143, 2001.

COMMUNAL C, SINGH K, SAWYER DB, COLUCCI WS: Opposing effects of beta(1)- and beta(2)-adrenergic receptors on cardiac myocyte apoptosis: role of a pertussis toxin-sensitive G protein. Circulation 100: 2210$2212,1999$. 
DRONJAK S, SPASOJEVIC N, GAVRILOVIC L, VARAGIC V: Effects of noradrenaline and serotonin reuptake inhibitors on pituitary-adrenocortical and sympatho-adrenomedullar system of adult rats. Neuro Endocrinol Lett 28: 614-620, 2007.

GANGULY PK, DHALLA KS, SHAO Q, BEAMISH RE, DHALLA NS: Differential changes in sympathetic activity in left and right ventricles in congestive heart failure after myocardial infarction. Am Heart J 133: 340-345, 1997.

GAVRILOVIC L, SPASOJEVIC N, DRONJAK S: Subsequent stress increases gene expression of catecholamine synthetic enzymes in cardiac ventricles of chronic-stressed rats. Endocrine 37: 425-429, 2010.

GREGOREVIC P, RYALL JG, PLANT DR, SILLENCE MN, LYNCH GS: Chronic beta-agonist administration affects cardiac function of adult but not old rats, independent of beta-adrenoceptor density. Am J Physiol Heart Circ Physiol 289: H344-H349, 2005.

GRIPPO AJ, MOFFITT JA, JOHNSON AK: Cardiovascular alterations and autonomic imbalance in an experimental model of depression. Am J Physiol Regul Integr Comp Physiol 282: R1333-R1341, 2002.

HAMMEN C: Stress and depression. Annu Rev Clin Psychol 1: 293-319, 2005.

HUANG J, SOPHER SM, LEATHAM E, REDWOOD S, CAMM AJ, KASKI JC: Heart rate variability depression in patients with unstable angina. Am Heart J 130: 772-779, 1996.

KAYE DM, LEFKOVITS J, COX H, LAMBERT G, JENNINGS G, TURNER A, ESLER MD: Regional epinephrine kinetics in human heart failure: evidence for extra-adrenal, nonneural release. Am J Physiol 269: H182-H188, 1995.

KENDLER KS, KARKOWSKI LM, PRESCOTT CA: Causal relationship between stressful life events and the onset of major depression. Am J Psychiatry 8156: 837-841, 1999.

KENNEDY B, BIGBY TD, ZIEGLER MG: Nonadrenal epinephrine-forming enzymes in humans. Characteristics, distribution, regulation, and relationship to epinephrine levels. J Clin Invest 95: 2896-2902, 1995.

KESSLER RC: The effects of stressful life events on depression. Annu Rev Psychol 48:191-214, 1997.

KHAMSSI M, BRODDE OE: The role of cardiac beta1- and beta2-adrenoceptor stimulation in heart failure. J Cardiovasc Pharmacol 16: S133-S137, 1990.

KUROKO Y, YAMAZAKI T, TOKUNAGA N, AKIYAMA T, KITAGAWA H, ISHINO K, SANO S, MORI H: Cardiac epinephrine synthesis and ischemia-induced myocardial epinephrine release. Cardiovasc Res 74: 43844, 2007.

KVETNANSKY R, MICUTKOVA L, KUBOVCAKOVA L, SABBAN EL, PALKOVITS M, KRIZANOVA O: Localization and regulation of phenylethanolamine N-methyltransferase gene expression in the heart of rats and mice during stress. Ann N Y Acad Sci 1018: 405-417, 2004.

LI H, MA SK, HU XP, ZHANG GY, FEI J: Norepinephrine transporter (NET) is expressed in cardiac sympathetic ganglia of adult rat. Cell Res 11: 317-320, 2001.

LIGGETT SB, TEPE NM, LORENZ JN, CANNING AM, JANTZ TD, MITARAI S, YATANI A, DORN GW 2ND: Early and delayed consequences of beta(2)-adrenergic receptor overexpression in mouse hearts: critical role for expression level. Circulation 101: 1707-1714, 2000.

LIVAK KJ, SCHMITTGEN TD: Analysis of relative gene expression data using real-time quantitative PCR and the 2(-Delta Delta C(T)) Method. Methods 25: 402-408, 2001.

MICUTKOVA L, KREPSOVA K, SABBAN EL, KRIZANOVA O, KVETNANSKY R: Modulation of catecholaminesynthesizing enzymes in the rat heart by repeated immobilization stress. Ann NY Acad Sci 1018: 424-429, 2004.

MYSLIVECEK J, RÍCNÝ J, KOLÁR F, TUCEK S: The effects of hydrocortisone on rat heart muscarinic and adrenergic alpha 1 , beta 1 and beta 2 receptors, propranolol-resistant binding sites and on some subsequent steps in intracellular signalling. Naunyn Schmiedebergs Arch Pharmacol 368: 366-376, 2003.

NERI M, CERRETANI D, FIASCHI AI, LAGHI PF, LAZZERINI PE, MAFFIONE AB, MICHELI L, BRUNI G, NENCINI C, GIORGI G, D'ERRICO S, FIORE C, POMARA C, RIEZZO I, TURILLAZZI E, FINESCHI V: Correlation between cardiac oxidative stress and myocardial pathology due to acute and chronic norepinephrine administration in rats. J Cell Mol Med 11: 156-170, 2007. 
PENG YX, SHAN J, QI XY, ZHANG SJ, MA SP, WANG N, LI JP, XUE H, WU M: The catecholamine-betaadrenoreceptor-cAMP system and prediction of cardiovascular events in hypertension. Clin Exp Pharmacol Physiol 33: 227-231, 2006.

RIEMANN B, SCHÄFERS M, LAW MP, WICHTER T, SCHOBER O: Radioligands for imaging myocardial alphaand beta-adrenoceptors. Nuklearmedizin 42: 4-9, 2003.

SANTOS IN, SPADARI-BRATFISCH RC: Stress and cardiac $\beta$-adrenoceptors. Stress 9: 69-84, 2006.

SPASOJEVIC N, GAVRILOVIC L, DRONJAK S: Different behavioral effects of maprotiline and fluxilan in rats. Arch Biol Sci 60: 33-39, 2008.

WANG GY, MCCLOSKEY DT, TURCATO S, SWIGART PM, SIMPSON PC, BAKER AJ: Contrasting inotropic responses to alpha1-adrenergic receptor stimulation in left versus right ventricular myocardium. Am J Physiol Heart Circ Physiol 291: H2013-H2017, 2006.

WHANG W, KUBZANSKY LD, KAWACHI I, REXRODE KM, KROENKE CH, GLYNN RJ, GARAN H, ALBERT $\mathrm{CM}$ : Depression and risk of sudden cardiac death and coronary heart disease in women: results from the Nurses' Health Study. J Am Coll Cardiol 53: 950-958, 2009.

YALÇIN F, YALÇIN H, SEYFELI E, AKGUL F: Stress-induced hypercontractility in patients with hypertension: an interesting imaging finding. Int J Cardiol 143: e1-e3, 2010.

ZHUANG SY, BRIDGES D, GRIGORENKO E, MCCLOUD S, BOON A, HAMPSON RE, DEADWYLER SA: Cannabinoids produce neuroprotection by reducing intracellular calcium release from ryanodine-sensitive stores. Neuropharmacology 48: 1086-1096, 2005. 